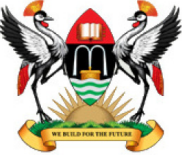

East African School of

Higher Education Studies \& Development
Makerere Journal of Higher Education

ISSN: $1816-6822 ; 3(1)(2011) \mathrm{X}-\mathrm{XX}$

DOI: http://dx.doi.org/10.4314/majohe.v3i2.1

(C) The Author(s) 2011

Reprints \& permission: EASHESD

http://ajol.info/majohe

\title{
Academic Accountability, Quality and Assessment of Higher Education in Nigeria
}

\author{
Uche Chineze $^{1, *}$, Clara O. Olele ${ }^{2}$ \\ ${ }^{1}$ Department of Educational Management \\ ${ }^{2}$ Department of Curriculum Studies and Educational Technology (University of Port Harcourt). \\ [ ${ }^{*}$ Corresponding author. E-mail: nezenwam@yahoo.com]
}

\begin{abstract}
This study examined quality assurance and academic accountability in ten higher education institutions in Nigeria, using UNESCO's input-processoutput framework for assessing the quality of education. Data were collected from staff and students of the universities as well as opinion leaders drawn from the communities hosting the institutions. The findings were that academic accountability, in terms of the quality of inputs and outputs, was low; the quality of the process was high; and that research activities and community service in the institutions enhance development of the communities in which the universities are located. Conversely, lack of political willingness to develop higher education, low students' learning readiness and non-utilisation of research findings were found to be affecting the academic accountability of the institutions. Therefore, interventions targeted at improving the quality of inputs into higher education; exposing students to practical training; and encouraging utilisation of research findings and university-community alignment are recommended.
\end{abstract}

Keywords: Academic accountability; Quality assurance; Community service

\section{$1 \quad$ Introduction}

Academic accountability implies that those who are given responsibility are held answerable for the education outcomes of the students or are aware of the duty to give stewardship account in terms of productivity and the quality of the products there of. The concept of accountability in education stresses the need for practitioners in education and stakeholders such as parents, education authorities, and communities to know what goes on in the education sector of the economy, not only with regard to how judiciously the money allocated to the sector is spent, but how much learning is taking place and how efficient and effective it is. Higher education plays three main roles towards the development 
of middle and high level manpower and national development i.e. teaching, research and community service. Societal changes and needs, in addition to global trends and high cost, have increased the expectations on the institutions of higher learning to be more responsive, functional and relevant in their programmes and services. Also, Berdahl and McConnell (1999) observe that the public is now more aware and conscious of the meaning and role of higher education. There is high demand for higher education and its services. Thus people are critical of what the institutions are doing and are becoming more vocal in expressing their desires of greater benefits. So universities and other higher educational institutions are expected to explain themselves, defend their character, and demonstrate that their services are worth the resources being expended on them. They must be accountable to the numerous stakeholders and agencies linked to them, for the range of their services and performance (teaching, learning, research and community service). Three types of academic accountability have been identified (Agabi, 2002; UNESCO, 2004).

1. Input or programme accountability

2. Process accountability

3. Outcome accountability

The quality of the input, the processes and the environment determines the quality of the output. Thus academic accountability provide answers to the questions on quality teaching staff, facilities, students input, the right processes for producing expected results, enabling environment and right type of teaching and learning instructional materials. Academic accountability is also concerned with the relevance of research activities in the institutions, the new knowledge produced for the development of communities, and the nation at large; and the benefits of the community service carried out by the lecturers and the students.

Therefore assessing the quality of higher education must be geared toward an integrated, customer-centred quality model. This is why UNESCO (2004) emphasized that quality must be linked to relevance, and quality must be seen as a multidimensional concept which depends to a large extent on the contextual setting of a given system. So the accountability is equally holistic and integrating. In the light of the multidimensional feature of quality, and by implication accountability, UNESCO (2004) developed an input-process-output framework which indicated the places or domains of all stake-holders in education in the pursuit of quality and accountability (learners, parents, teachers, communities, government, at the various levels, classroom, school, national policy etc).

In the light of the multidimensional feature of quality and the holistic approach to academic accountability, UNESCO (2004) developed a framework which helps to guide a step-by-step assessment of educational quality (Figure $1)$. 
INPUTS

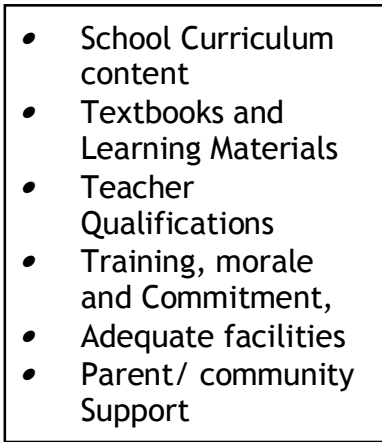

Student characteristics

- Aptitude, ability

- Perseverance

- Commitment Nutrition and health School readiness Attend FCCE

- Household/ community

- Characteristics

- Household Income

- Cultural/ Religious

- Factors

- Community

- Economic and

- Labour market conditions
PROCESS

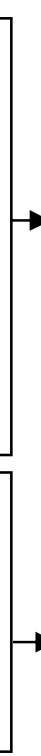

- School Climate

- High expectation

- $\quad$ Strong leaders

- Positive Teacher Attitudes

- Safe and gender sensitive environment

- Incentives for good Results

- Flexibility/ Autonomy

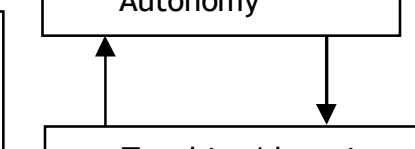

- Teaching/ learning

- Sufficient learning

- Time

- Active teaching methods

- Integrated system for assessment and feedback

- $\quad$ Appropriate class size

- Appropriate use of language
OUTCOMES

- Achievement

- Cognitive, Development

- Literacy, generic skills, Good Citizenship, Personal Development, Positive attitude towards Learning

- Healthy behaviours Attainment,

- Formal completion

- Diploma/ Qualifications

- Standards

- Official Learning Objective

- (Desire outcomes)

Figure 1: Input-Process-Output Framework for Assessing Educational Quality Source: Adapted from Jaap (2004); Obanya (2010)

\subsection{Question of Moral Character Development in a School Setting}

In Figure 1, it can be observed that quality inputs (politics, policies, human resources, material resources, financial resources, environment) subjected to quality processing (transformational processing through effective leadership, teacher professional support process, learners psycho-social support process, effective teaching-learning process) lead to quality output. It is only quality processing of quality input that can yield quality outcomes and this can manifest in success in examinations, cognitive learning enhancement, high level of life-coping and life-long learning skills. These skills developed in the quality student outputs enhance the capacity of the graduates to contribute to 
societal development, created through a self-sustaining and self-generating educational system for sustainable development of the society (UNESCO, 2004; Obanya, 2010; Okobukola, 2010).

\subsection{Related Literature}

The basic system theory of organization recognizes systems as characteristically composed of five parts (Agabi, 2002 Smith 1957). These are inputs, a transformation process, outputs, feedback and the systems' environment. The inputs are the human, materials and non-tangible resources (like the norms, rules and tradition) that are needed for the system's operational activities. These inputs pass through some technical processes (like the classroom instructions and control activities) and behavioural changes (transformation process). The feedback is the reactions (positive or otherwise) of the environment to the outputs or services from the system. Such feedback forms the basis for determining the subsequent input, transformation process and hence output from the system. The system environment is the social, political and economic forces around the system, which ultimately determines the focus, capabilities and inhibitions of the system.

As a system, the higher education organization has these characteristics. The quality implication of each of these components needs to be examined closely as it particularly interferes with their accountability for the achievement of higher education goals.

1. The input component: the input components of higher education include the people (students and staff) and the resources (like the furniture and fittings, the instructional materials, texts and learning material needed for instructions). Others include the information resources as well as the nonmaterial components like the norms, values and standards regulating the instructional activities. As a system component, input determines the nature of the transformation process and not just the quantity but also the quality of output i.e. the student graduates (Sallis 2002; Rao 2008, Onyene, Ikebude \& Uche, (2009).

2. The staff input: The people working in the higher education both as academic and non-academic staff are also the input into higher education from the society. (Uche 2010) opines that accountability for quality in higher education requires high consideration on teacher qualification, training, morale and commitment as specified by UNESCO, (2002).

3. The students input: Students are the major input into the higher education with their characteristics as a carryover from the larger social system. They also come in with their learning behaviour, ability, perseverance, commitment, nutrition and health issues which affect the teaching and learning process and academic accountability positively or otherwise. 
4. Resources input involve both the fund and the facilities. The Structural infrastructures like space acquisition, maintenance and renewal are school resources that must be put together to ensure quality outcome (Uche, Okoli \& Ahunanya, 2010). Other resource inputs are curriculum content, text books, learning materials, and adequate facilities.

5. The transformation process: The basic activities of teaching, learning, evaluation and the managerial elements of the higher educational process constitute the transformation process (Okorie \& Uche 2008). According to the framework developed by UNESCO (2002) school, teaching/learning time, students' participation, methods, system for assessment and feedback, class size and appropriate language are the identified transformational process that requires quality touch in order to yield quality outcome. Transformational quality is achieved not through adhering to systems and procedures, but through the exercise of leadership. It is leadership that establishes a vision that translates into customer service and builds the structures and organizational culture that empowers staff to deliver a quality service that produce quality outcome (Sallis 2002; Creech 1994). The nature and efficacy of the transformation process in higher education is not dependent on one unit but on all the elements of the institutions' programmes (Babalola 2008; Amadike, 2007; Mbakwem \& Okeke 2007).

6. The output component: The output constitutes the ultimate goal of the system as a functional entity. It reflects the relevance and impact of services rendered in higher education. It is the learning outcome or behaviour modifications that have been achieved through the teaching and learning process and other programmes organized in the institutions (Jaiyeoba \& Atanda 2007; Mishra, 2008). This is identified through the evaluation process and reflected in development of skills, good citizenship, positive attitudes, healthy behaviours and attainment of high standards and placements (Agabi \& Uche, 2000).

\subsubsection{Research and Community Service}

Academic accountability is also considered in terms of the quality of research activities and community service carried out by lecturers and students because research and knowledge production are part of their roles. Production of knowledge and dissemination of information through research contribute immensely to the development of the staff, students and the community as a whole (Uche 1999). Universities render community services to the community through the lecturers and students by assisting national development through their extra-mural and extension services, agricultural extension services as well as rural health services in their various departments (Nnabuo \& Uche 1999; Mishra 2008). 


\subsubsection{Academic Accountability and Quality Assessment in Higher Education}

The process by which educational administrator, teachers and other stakeholders monitor and assess the quality of education in the higher education institutions is called academic accountability (Reiley, 1992; Crosby, 1979). The high cost of education has made the public and other stakeholders to begin to ask for the relationship between the cost of education (resources allocated to it, e.g. time and efforts put in by students and their teachers) and the end product of the education which is the human resource that result from the educational process. To remove this doubt, Babalola (2008) suggests that there is need for Nigerian higher education to be truly accountable by setting objectives, developing programmes to meet the set objectives, carrying out the designed programmes, evaluating and measuring the degree of success and failures and making a continuous improvement. Since higher education certifies their graduates fit in learning and character, accountability for their programmes and outcomes should mean accounting for all the resources put in, the process/actions taken and the output/results to the society that owns it (Uche, 2010; Joshua (2005) Smith (1971) Gronhind (1976, Joshua (2005)

\subsubsection{Constraints to Academic Accountability and Quality}

However important academic accountability is, it is difficult to access quality in higher education because it is multidimensional and embraces all functions and activities within and outside the system. According to Amadike (2007); Dike (2006); Uche, (2010); Uche, Okoli \& Ahunanya, (2010) lack of adequate funding, corruption, inadequate facility, overpopulation, lecturers' absenteeism, lack of regular supervision and unfriendly learning environment are major constraints to quality delivery of higher education programmes in Nigeria. If these problems are not sincerely and holistically tackled, the quality of the output will not be guaranteed and the achievement of the objectives of higher education may become a mirage, Onyene, Ikebude and Uche (2009) warned.

\subsection{Statement of Problem}

Higher education by its nature and goals is being looked upon to produce high and middle level human resources for the national and economic development of Nigeria, more so in the southern part of the country. This part of the country is significant because it is where Niger Delta, the oil producing area, is located with all the challenges of oil exploration and production and yet poverty and youth restiveness due to lack of development and long time neglect. It is also the location of eastern Nigeria whose indigenes are known to be more business incline than education; and so are facing the challenges of prolonged period of 
ignorance of the value of education. Also, the public is now more aware and conscious of the meaning and role of higher education. There is high demand for higher education and its services in the Southern States of Nigeria. Consequently higher education is now being asked to be increasingly answerable (accountable) to its constituencies for the range of its services and the effectiveness of its performance (outcome), no matter the level of autonomy and academic freedom its operators may claim. This study therefore aimed at adopting the UNESCO 2002 input-process-output framework to assess the level of academic accountability in terms of the quality of their input, process and outcome. Other issues investigated in this study include the level of academic accountability in terms of the impact of research activities and community service carried out by lecturers and students and the constraints of academic accountability and quality assessment in higher education.

\subsection{Purpose}

The purpose of the study was to assess the academic accountability of Nigerian higher education in terms of the quality of the input, process and outputs by the institutions under study. Specifically the study tried to assess:

1. Academic accountability in terms of the quality of the input in the institutions

2. Academic accountability in terms of the quality of the process in the institutions

3. Academic accountability in terms of the quality of the output from the institutions

4. Academic accountability in terms of the impact of the research activities among the lecturers

5. Academic accountability in terms of the impact of the community service by the lecturers and examine the constraints of academic accountability in the institutions.

\subsection{Research Questions}

1. What is the level of academic accountability in terms of the quality of the inputs?

2. What is the level of academic accountability in terms of the quality of the process?

3. How can the quality of the output of the teaching and learning process be rated?

4. What degree of impact do research activities by lecturers have on the development of communities and institutions? 
5. In what ways does the community service by the lecturers enhance the community development?

6. What are the constraints of academic accountability in the institutions?

\subsection{Hypotheses}

1. There is no significant difference between lecturers and students in their assessment of academic accountability in terms of the quality of the inputs

2. There is no significant difference between the students and the lecturers in their assessment of academic accountability in terms of the quality of the process in the institutions

3. There is no significant difference among the lecturers, students and community leaders in their assessment of quality of the output of the teaching and learning process

4. There are no significant differences between federal and state institutions in their assessment of the impact research activities by lecturers have on the development of the community and institutions.

5. There is no significant relationship between the quality of input and the quality of output of the teaching and learning process in the institutions.

\section{$2 \quad$ Methodology}

This study adopted a descriptive survey design to assess the level of academic accountability in terms of the quality of input, process, output and impact of research and community service in higher education. The sample size was drawn from a population of all the higher education institutions in Southern States of Nigeria. It included 150 lecturers, 350 final year students and 200 opinion leaders from the host community to the institutions randomly selected from 10 out of 45 institutions of higher learning in the 10 States. Thus the sample size of 700 respondents was used for the study. Two sets of questionnaire (one set for students and lecturers and one for the community people) titled" Level of academic accountability and quality assessment questionnaire $1 \& 2 "$ (LAAQAQ 1\& 2) were developed by the researchers, validated by experts in measurement and evaluation and certified reliable for the study through a test re test process which yielded a coefficient of $0.76 \mathrm{r}$. LAAQAQ 1 an 80 item questionnaire was administered to the students and lecturers while LAAQAQ 2 contained 54 items and was administered to the community opinion leaders within the host communities to the institutions. All the questionnaires administered were returned. Since the items in the questionnaire were weighted in four point Likert scale the criterion mean of 2.50 was adopted for judgment (very high level-4; higher level-3; low level 2; 
very low level-1 and strongly agree-4; agree-3; disagree-2; strongly disagree-1). Mean scores and standard deviation were used to analyze the responses to the general research questions while t-test, Pearson's Moment Product Coefficient and Analysis of variance, ANOVA were used to test the hypotheses at significant level of 0.05 . For the purpose of the test of ANOVA the opinions of 15 Community chairmen (CDC were specifically selected to be compared with the categories of respondents (students and teacher)

\section{$4 \quad$ Findings}

\subsection{Academic Accountability in Terms of the Quality of the Inputs}

Table 1: Quality of Inputs into Higher Education

\begin{tabular}{llll}
\hline Items & Mean & SD & Remarks \\
\hline Curriculum content is comprehensively developed & 2.95 & 0.77 & High \\
Current and relevant textbooks are available & 2.58 & 0.84 & High \\
Learning materials are adequately used & 2.36 & 0.75 & low \\
Lecturers are qualified, always available and competent & 2.70 & 0.74 & High \\
Lecturers are well trained, motivated and committed & 2.48 & 0.88 & Low \\
Adequate facilities and conducive learning environment & 2.19 & 2.24 & Low \\
Parents/community support is provided & 2.13 & 0.68 & Low \\
Students behaviour are generally satisfactory & 2.28 & 0.76 & Low \\
Students are always ready to learn & 2.41 & 0.83 & Low \\
Students are committed and have the ability to persevere & 2.51 & 0.85 & High \\
Students cooperate in health, sport and rules on campus. & 2.52 & 0.90 & High \\
Parents have positive attitude to education of their children & 2.77 & 0.89 & High \\
Household income is generally high & 2.29 & 0.88 & Low \\
Cultural/religious values have influence in the school & 2.50 & 0.83 & High \\
Community economic base is strong for institutional support & 2.52 & 0.89 & High \\
There is linkage between institutions and labour market & 2.52 & 0.86 & High \\
Overall mean & 2.48 & & \\
\hline
\end{tabular}

From Table 1, respondents indicated that the curriculum content is comprehensively developed (mean $=2.95 ; \mathrm{SD}=0.77$ ); that current and relevant textbooks are available (mean $=2.58 ; \mathrm{SD}=0.84$ ). It shows that learning material are not adequately used (mean=2.36; $\mathrm{SD}=0.75$ ). Again, the result show that lecturers are qualified, always available and competent (mean=2.70; $\mathrm{SD}=0.74$ ); that they are committed and have the ability to persevere (mean=2.51; $\mathrm{SD}=0.85$ ). It also indicate that students cooperate in health, sport and rules on 
campus (mean=2.52; $\mathrm{SD}=0.90$ ); and that the parents have positive attitude towards education of their children (mean $=2.77 ; \mathrm{SD}=0.89$ ). Furthermore, the result on the table showed that cultural and religious values have influence in the school (mean=2.50; $\mathrm{SD}=0.83$ ); that community economic base is strong for institutional support (mean=2.52; $\mathrm{SD}=0.89$ ), and that there is appropriate linkage between the labour market and the institution (mean=2.52; $\mathrm{SD}=0.86$ ). However, from the table, students indicated that lecturers are not well trained, motivated and committed (mean $=2.48 ; \mathrm{SD}=0.88$ ); that there are no adequate facilities and conducive learning environment (mean=2.19; $\mathrm{SD}=2.24)$, and that parents/community support is not provided (mean $=2.13 ; \mathrm{SD}=0.68$ ). In the same vein, the result showed that students behaviour are generally unsatisfactory $(m e a n=2.28 ; \mathrm{SD}=0.76)$. Students are not always ready to learn (mean=2.41; $\mathrm{SD}=0.83$ ), and that household income is not generally high (mean=2.29; $\mathrm{SD}=0.88)$.

\subsection{Academic Accountability in Terms of the Quality of the Process}

Table 2: Academic Accountability in Terms of the Quality of the Process

\begin{tabular}{lll}
\hline Items & Mean SD & Remarks \\
\hline The leadership in the institution is very effective & 2.80 & 0.82 High \\
Lecturers have positive attitude & 2.73 & 0.84 High \\
Institution's environment is safe, friendly and gender sensitive & 2.50 & 0.85 High \\
There are incentives for good results & 2.35 & 0.83 Low \\
There is flexibility in operation & 2.42 & 0.81 Low \\
Institutional autonomy is being fully implemented & 2.31 & 0.87 Low \\
There is sufficient learning time for the programmes & 2.32 & 0.76 Low \\
Teaching and learning is very effective & 2.43 & 0.76 Low \\
There are active teaching methods & 2.38 & 0.77 Low \\
There is integrated system for assessment and feedback & 2.66 & 0.87 High \\
There is appropriate class size (i.e. teacher/students ratio) & 2.40 & 0.86 High \\
There is appropriate use of language & 2.80 & 0.76 High \\
Overall mean & 2.51 & \\
\hline
\end{tabular}

From Table 2, the mean value of 2.80 and standard deviation of 0.82 show that the leadership in the institution is very effective. The results also indicate that lecturers have positive attitude (mean=2.73; $\mathrm{SD}=0.84$ ); and that the institutions environment is safe, student friendly and gender sensitive (mean=2.50; $\mathrm{SD}=0.85$ ). Accordingly, the mean value of 2.66 and standard deviation 0.87 indicate that there is integrated system for assessment and feedback. Also, students indicated appropriate use of language (mean=2.80; $\mathrm{SD}=0.76$ ). On the other hand, the results show that there are no incentives for good results 
(mean=2.35; $\mathrm{SD}=0.83$ ); there is no flexibility in operations (mean=2.42; $\mathrm{SD}=0.81$ ), and that institutional autonomy is not being fully implemented (mean=2.31; $\mathrm{SD}=0.87$ ). in the same direction, the mean value of 2.32 and standard deviation of 0.76 show that there is no sufficient learning time for the programme; teaching and learning process is not very effective $($ mean $=2.43 ; \mathrm{SD}=0.76)$ and that there are no active teaching methods (mean $=2.38 ; \mathrm{SD}=0.77$ ). Also, the class size is not appropriate in terms of teacher/students ratio (mean $=2.40 ; \mathrm{SD}=0.86$ ).

\subsection{Quality of the Output of the Teaching and Learning Process}

Table 3: Accountability in Terms of the Quality of the Outputs

\begin{tabular}{|c|c|c|c|c|c|}
\hline \multirow[b]{2}{*}{ Items } & \multicolumn{3}{|c|}{$\begin{array}{l}\text { Students \& } \\
\text { lecturers }\end{array}$} & \multicolumn{2}{|c|}{$\begin{array}{l}\text { Community } \\
\text { leaders }\end{array}$} \\
\hline & Mean & SD & Remarks & Mean & Remarks \\
\hline $\begin{array}{l}\text { Students have achieved their aim of being in } \\
\text { the institution }\end{array}$ & 2.43 & 0.78 & 3 Low & 2.78 & $0.96 \mathrm{High}$ \\
\hline $\begin{array}{l}\text { Students have reached a high level of } \\
\text { literacy, generic and skill development. }\end{array}$ & 2.39 & 0.73 & 3 Low & 2.70 & $0.64 \mathrm{High}$ \\
\hline $\begin{array}{l}\text { Students have developed to level of good } \\
\text { citizenship. }\end{array}$ & 2.39 & 0.75 & Low & 2.62 & 0.64 High \\
\hline $\begin{array}{l}\text { Students have reached high level of personal } \\
\text { development }\end{array}$ & 2.47 & 0.79 & Low & 2.34 & 0.79 Low \\
\hline $\begin{array}{l}\text { Students now have positive attitude towards } \\
\text { learning }\end{array}$ & 2.48 & 0.84 & 4 Low & 3.06 & 0.92 High \\
\hline Students have 3 healthy behaviour & 2.42 & 0.75 & 5 Low & 2.34 & 0.65 Low \\
\hline $\begin{array}{l}\text { All students have attained formal } \\
\text { completion of their programme }\end{array}$ & 2.47 & 0.78 & 3 Low & 2.56 & 0.65 High \\
\hline $\begin{array}{l}\text { Institutional outputs are of high standards in } \\
\text { terms of the official learning objectives }\end{array}$ & 2.56 & 0.78 & 3 High & 2.71 & 0.78 High \\
\hline $\begin{array}{l}\text { They possess the desired and socially } \\
\text { acceptable values }\end{array}$ & 2.54 & 0.81 & 1 High & 2.72 & 0.45 High \\
\hline $\begin{array}{l}\text { Both lecturers and students have become } \\
\text { the role model in the society }\end{array}$ & 2.64 & 0.85 & High & 2.53 & 0.90 High \\
\hline Overall mean & 2.48 & & & 2.64 & high \\
\hline
\end{tabular}

From table 3, the overall mean shows that the community people rated the output higher (2.64) than the students and lecturers (2.48). While students and lecturers believe that students have not achieved their aim of being in the institution (mean=2.43; $\mathrm{SD}=0.78$ ); that students have not reached a high level of literacy, generic and skill development (mean=2.39; SD=0.73), the community people think otherwise (2.78 and 2.70). However the result show all the categories of the respondents agree that students and lecturers have become 
role models in the society (2.64 for students and lecturers and 2.53 for community people).

\subsection{Impact of Lecturers' Research Activities on Community Development}

Table 4: Impact of Lecturers' Research Activities on Community Development

\begin{tabular}{lllll}
\hline Items & Mean SD & Remarks Mean SD & Remark \\
\hline Helps staff training & 2.87 & $0.90 \mathrm{High}$ & 2.99 & $0.95 \mathrm{High}$ \\
Attracts funds and equipments to institution & 2.58 & $0.80 \mathrm{High}$ & 2.72 & $0.74 \mathrm{High}$ \\
Improvement of teaching quality & 2.84 & $0.79 \mathrm{High}$ & 2.73 & $0.62 \mathrm{High}$ \\
Helps staff advancement through promotion & 2.84 & $0.87 \mathrm{High}$ & 2.87 & $1.00 \mathrm{High}$ \\
Increasing awareness of new knowledge & 2.83 & $0.85 \mathrm{High}$ & 2.91 & $0.67 \mathrm{High}$ \\
Enhancing development and improvement of & 2.61 & $0.83 \mathrm{High}$ & 2.91 & $0.79 \mathrm{High}$ \\
industry's products and services. & & & \\
Findings lead to solutions of societal problems & 2.58 & $0.91 \mathrm{High}$ & 2.64 & $0.64 \mathrm{High}$ \\
Collaboration between staff/ institution/ & 2.53 & $0.89 \mathrm{High}$ & 2.37 & $0.64 \mathrm{Low}$ \\
community & 2.61 & $0.91 \mathrm{High}$ & 2.92 & $0.50 \mathrm{High}$ \\
Social networking & 2.70 & & 2.78 & \\
Overall mean & & & & \\
\hline
\end{tabular}

From the data in table 4, the research activities among lecturers has a high degree of impact on the development of the institutions and communities, (overall mean of 2.70 for students and lecturers and 2.78 for community leaders); helps staff training(mean $=2.87 ; \mathrm{SD}=0.90,2.99 ; 0.95)$; it also attract fund and equipments to institutions (mean $=2.58 ; \mathrm{SD}=0.80,2.72 ; 0.74)$, and also, that there is social networking(mean $=2.61 ; \mathrm{SD}=0.91,2.92 ; 0.50)$. However, the results did not agree that there is collaboration between staff/institution/community (mean=2.53; $\mathrm{SD}=0.89,2.37 ; 0.64$ ). Community leaders assessed this item low (mean=2.37). 


\subsection{Impact of Lecturers' Community Service Activities on Community Development}

Table 5: Impact of Lecturers' Community Service Activities on Community Development

\begin{tabular}{|c|c|c|c|c|c|c|}
\hline \multirow[b]{2}{*}{ Items } & \multicolumn{3}{|c|}{$\begin{array}{l}\text { Students \& } \\
\text { lecturers }\end{array}$} & \multicolumn{3}{|c|}{$\begin{array}{l}\text { Community } \\
\text { leaders }\end{array}$} \\
\hline & Mean & SD & Remarks & Mean & SD & Remarks \\
\hline $\begin{array}{l}\text { Community development through skills } \\
\text { acquisitions projects by lecturers \& students }\end{array}$ & 2.66 & 0.83 & High & 2.82 & 0.58 & 8 High \\
\hline Regular heath talks organized for community & 2.58 & 0.83 & High & 2.90 & 0.79 & 9 High \\
\hline $\begin{array}{l}\text { Encouraging political awareness and } \\
\text { participation through political education }\end{array}$ & 2.64 & 0.81 & High & 3.01 & 0.73 & 3 High \\
\hline $\begin{array}{l}\text { Instilling values of good practice and free } \\
\text { enterprise }\end{array}$ & 2.79 & 0.84 & t High & 2.82 & 0.72 & 2 High \\
\hline $\begin{array}{l}\text { Providing teaching and training for } \\
\text { environmental hygiene in the community }\end{array}$ & 2.74 & 0.86 & High & 2.81 & 0.94 & 4 High \\
\hline $\begin{array}{l}\text { Organizing ICT literacy programmes for } \\
\text { community }\end{array}$ & 2.66 & 0.80 & High & 2.90 & 0.67 & 7 High \\
\hline $\begin{array}{l}\text { Campaign for self development and good } \\
\text { citizenship }\end{array}$ & 2.71 & 0.77 & High & 2.44 & 0.79 & 9 High \\
\hline $\begin{array}{l}\text { Providing innovative ideas and leadership } \\
\text { through involvement in community meetings }\end{array}$ & 2.65 & 0.80 & High & 3.06 & 0.68 & 3 Low \\
\hline Organizing extra-moral classes & 2.52 & 0.86 & High & 2.81 & 0.84 & 4 High \\
\hline Organizing adult literacy programmes & 2.53 & 0.87 & High & 2.78 & 0.72 & 2 High \\
\hline $\begin{array}{l}\text { Organizing youth development and } \\
\text { empowerment programmes }\end{array}$ & 2.63 & 0.89 & High & 2.61 & 1.07 & 7 High \\
\hline Participating in farming activities & 2.50 & 0.84 & High & 2.57 & .091 & 1 High \\
\hline $\begin{array}{l}\text { Engineering activities for innovative and } \\
\text { indigenous adaptive technology. }\end{array}$ & 2.46 & 0.96 & Low & 3.29 & 0.86 & 6 High \\
\hline Overall mean & 2.62 & & & 2.83 & & High \\
\hline
\end{tabular}

From table 5, almost all the items were accepted as ways community service in the institutions enhance community service (0verall mean of 2.62 for students and lecturers and 2.83 for community leaders) Respondents indicated that there is community development through skills acquisitions projects carried out by lecturers and students (mean=2.66; $\mathrm{SD}=0.83,2.82 ; 0.58$ ), instilling the values of practice and free enterprise through entrepreneurship education (mean=2.79; $\mathrm{SD}=0.84,2.82 ; 0.72$ ). It provides teaching and training for environmental hygiene in the community (mean=2.74; $\mathrm{SD}=0.86$ ). Also, there is campaign for self development and good citizenship (mean=2.71; $\mathrm{SD}=0.77$ ) as agreed by students and lecturers though the community leaders disagreed to this $(2.44$; $0.79)$.

However, the mean value of $2.46(\mathrm{SD}=0.96)$ for students and lecturers 
indicates there is no engineering activities for innovative and indigenous adaptive technology though community leaders accepted the item (mean=3.29 and $\mathrm{SD}=0.86$ ).

\subsection{Constraints to Academic Accountability}

Table 6: Constraints to Academic Accountability

\begin{tabular}{lllllll}
\hline Items & Mean SD & Remarks & Mean SD & Remarks \\
\hline Gross inadequate funding & 2.65 & 0.99 & High & 3.36 & 0.48 & High \\
Dramatic increase in students input & 2.63 & 0.94 & High & 3.18 & 0.71 & High \\
Students are not ready to learn & 2.63 & 0.98 & High & 3.02 & 0.74 & High \\
Students are distracted by societal activities & 2.47 & 0.96 & Low & 3.28 & 0.95 & High \\
Decline in teaching and research facilities & 2.56 & 0.95 & High & 3.11 & 0.79 & High \\
Poorly remunerated staff & 2.46 & 0.94 & Low & 3.29 & 0.61 & High \\
Low staff strength & 2.49 & 0.93 & Low & 3.01 & 0.74 & High \\
Lack of competence in the faculty members & 2.37 & 0.87 & Low & 3.09 & 0.79 & High \\
Lecturers are not available most of the time & 2.40 & 0.92 & low & 2.91 & 0.79 & High \\
Inadequate time for teaching and learning & 2.55 & 0.89 & High & 3.46 & 0.65 & High \\
Inadequate books and journal subscription & 2.77 & 0.95 & High & 2.83 & 0.71 & High \\
Impaired teaching and learning environment & 2.71 & 0.94 & High & 2.76 & 0.87 & High \\
Poor quality of students input & 2.58 & 0.89 & High & 2.74 & 0.98 & High \\
Low parents/ community support & 2.39 & 0.95 & Low & 3.01 & 0.74 & High \\
Bad leadership & 2.54 & 0.97 & High & 3.07 & 1.00 & High \\
Political instability & 2.62 & 10.2 & High & 3.36 & 0.77 & High \\
Lack of political support for implementation & 2.83 & 0.99 & High & 2.93 & 0.80 & High \\
of higher education policies & & & & & & \\
Political insincerity in developing higher & 2.82 & 0.93 & High & 3.02 & 0.75 & High \\
education & 2.72 & 0.95 & High & 2.92 & 1.01 & High \\
Low income base of household & 2.77 & 0.90 & High & 2.92 & 0.91 & High \\
Lack of effective linkage mechanism & 2.76 & 0.99 & High & 3.21 & 0.72 & High \\
between institutions and labour market & 2.61 & & & 2.92 & & \\
Non-utilization of research findings & & & & & &
\end{tabular}

The high overall means by the respondents show that all the items listed in the table 6 above are constraints to academic accountability and quality in higher education (2.61 for students and lecturers and 2.92 for community leaders). The students and lecturers however indicated that students are not highly distracted by other societal activities (mean $=2.47 ; \mathrm{SD}=0.96$ ); that staffs are not poorly remunerated (mean=2.46; $\mathrm{SD}=0.94)$; that the staff strength is not low (2.49; $\mathrm{SD}=0.93$ ) while the community leaders disagreed. Also, both categories of respondents show that there is political instability (mean $=2.62 ; \mathrm{SD}=1.02,3.66$; .77 ), and there is lack of political willingness to support the implementation of 
higher education policies (mean $=2.83 ; \mathrm{SD}=0.99,2.93^{\prime} 0.80$ ). Furthermore, the mean value of $(2.77, \mathrm{SD}=0.90)$ for students and lecturers and $(2.92,0.91)$ for community leaders indicate that there is lack of effective linkage mechanism between institutions and the labour market, and the mean value of $(2.76, \mathrm{SD}=$ $0.99)$ for students and lecturers and mean of $(3.21, \mathrm{SD}=0.72)$ for community leaders indicate non usage of research findings as constraints to accountability.

\subsection{Significance of Findings}

Table 7: Significance of Assessment of the Quality of Inputs and Processes

\begin{tabular}{|c|c|c|c|c|c|c|c|c|}
\hline Hypothesis & Categories & $\mathbf{N}$ & Mean & SD & Df & Z-cal & Z-tab & Remarks \\
\hline $\begin{array}{l}\text { 1. There is no significant } \\
\text { difference between }\end{array}$ & Lecturers & 186 & 37.83 & 6.47 & 483 & -5.23 & 1.96 & Significant \\
\hline $\begin{array}{l}\text { lecturers and students in } \\
\text { their assessment of the } \\
\text { quality of the inputs }\end{array}$ & Students & 299 & 40.89 & 5.95 & & & & \\
\hline $\begin{array}{l}\text { 2. There is no significant } \\
\text { difference between the } \\
\text { students and the }\end{array}$ & Lecturers & 186 & 29.48 & 5.01 & 483 & -1.89 & 1.96 & $\begin{array}{l}\text { Not } \\
\text { significant }\end{array}$ \\
\hline $\begin{array}{l}\text { lecturers in their } \\
\text { assessment of the } \\
\text { quality of the process }\end{array}$ & Students & 299 & 30.36 & 5.01 & & & & \\
\hline $\begin{array}{l}\text { 4. There is no significant } \\
\text { difference between } \\
\text { federal and state }\end{array}$ & $\begin{array}{l}\text { Federal } \\
\text { university }\end{array}$ & 210 & 24.96 & 4.74 & 483 & 1.04 & 1.96 & $\begin{array}{l}\text { Not } \\
\text { significant }\end{array}$ \\
\hline $\begin{array}{l}\text { institutions in their } \\
\text { assessment of the } \\
\text { quality of output }\end{array}$ & $\begin{array}{l}\text { State } \\
\text { university }\end{array}$ & 275 & 24.51 & 4.73 & & & & \\
\hline
\end{tabular}

Table 7 shows the mean score for lecturers is $37.83(\mathrm{SD}=6.47)$ while mean score for students is 40.89 ( $\mathrm{SD}=5.95)$. This is with respect to their assessment of the quality of the inputs. Since the Z-calculated value of 5.23 is greater than $Z$ tabulated value of 1.96, we reject the null hypothesis. Therefore, there is significant difference between lecturers and students in their assessment of the quality of the input. The mean score for lecturers is $29.48(\mathrm{SD}=5.01)$ while that of the students is $30.36(\mathrm{SD}=5.01)$. This is with respect to their assessment of the quality of the process in the institution. Since the $Z$-cal. Value of 1.89 is less than the Z-tab. Value of 1.96, the null hypothesis is accepted. Thus, there is no significant difference between the students and the lecturers in their assessment of the quality of the process in the institution. The findings on the third hypothesis (i.e. "there are no significant differences among lecturers, students and community development chairmen (CDC) in their assessment of quality output of the higher education") are summarized in Table 8. Regarding 
hypothesis four, the results in Table 7 indicate that the mean score for federal institutions is $24.96(\mathrm{SD}=4.74)$ while that of state institutions is 24.52 $(\mathrm{SD}=4.73)$. This result is with respect to their assessment of the quality of output. Since the Z-cal value of 1.04 is less than the Ztab value of 1.96, then, the null hypothesis is accepted. This implies that there is no significant difference between federal and state institutions in their assessment of the quality of output.

Table 8: ANOVA in Respondents' Views

\begin{tabular}{|c|c|c|c|c|c|}
\hline Source & Some of squares & df & Mean square & F-calc F-tab & Remarks \\
\hline Between Groups & 282.546 & 2 & 141.273 & *6.218 3.02 & Significant \\
\hline Within Groups & 11291.156 & 497 & 22.719 & & \\
\hline Total & 11573.702 & 499 & & & \\
\hline \multicolumn{6}{|c|}{ Post Hoc Multiple Comparisons } \\
\hline \multicolumn{2}{|l|}{ Variables } & \multicolumn{3}{|c|}{$\mathrm{N}$} & Means \\
\hline \multicolumn{2}{|l|}{ Lecturers } & \multicolumn{3}{|l|}{186} & $24.156 a$ \\
\hline \multicolumn{2}{|l|}{ Students } & \multicolumn{3}{|l|}{299} & $25.047 a$ \\
\hline \multicolumn{2}{|c|}{ Community Development Chairmen } & \multicolumn{3}{|c|}{15 (specifically selected for this test) } & $23.333 b$ \\
\hline
\end{tabular}

A cross section of the community opinion leaders was specifically selected to compare their opinion with that of the lecturers and students using ANOVA. Thus only 15 of them who are the community development chairmen were selected for this purpose. The F-calculated value of 6.218 which is greater than the F-tabulated value of 3.02 suggests that there are significant differences among the three groups (Table 8).

A further test was conducted using the Scheffe Multiple Comparisons Test. From the analysis lecturers' mean score was 24.156, while students' mean score was 25.047. However, mean score for community leaders was 23.33. A perusal at Table 8 reveals that there was no significant difference between mean scores of lecturers and students, but significant differences were recorded between lecturers and community leaders on the one hand and students and community on the other hand.

The hypothesis that "there is no significant relationship between the quality of the input and the quality of the output" was verified using Pearson's Correlation Test (Table 9).

Table 9: Relationship between the Quality of Inputs and Outputs

\begin{tabular}{lccl}
\hline Variables & r-cal & r-tab & Remark \\
\hline $\begin{array}{l}\text { Quality of input versus quality of } \\
\text { output }\end{array}$ & 0.461 & 0.098 & $\begin{array}{l}\text { There is a significant } \\
\text { relationship }\end{array}$ \\
\hline
\end{tabular}


Table 9 shows the correlation between the quality of inputs and the quality of output. Form the table, since the r-cal value of 0.461 is greater than the r-tab value of 0.098 , the null hypothesis is rejected. Therefore, there is significant relationship between the quality of input and the quality of output of the teaching and learning process in the institutions.

\section{Discussion}

This study has found out that the level of academic accountability in terms of the quality of the input is generally low. This is worrisome because the input determines the nature of the transformation process and the quality of output of goods or service from the system. If the quality of the input components of higher education which include the people (students and staff),material resources, information resources as well as the non-material components like the norms, values and standards regulating the instructional activities cannot be guaranteed as indicated in this finding, the quality of the output will also be affected. If the students are not ready to learn they will engage in other social vices such as cultism and exam malpractice which will be detrimental to their lives, peace and development of the society. This finding is not surprising when we consider the characteristic, and nature of Southern Nigeria where the study was carried out; South East is known for business and South-South is known for the oil exploration and production. It is expected that the money being generated from the business and oil production activities will be used to develop the institutions in these areas. However the physical observation indicates that this is not reflected in the infrastructural development in the institutions, rather students are being distracted by social activities and the quest of making quick money. Uche, Okoli and Ahunanya, 2010 Uche 2010) also recorded the same findings from their studies. The findings also show that there is significant difference in the opinions of the students and lecturers with students indicating stronger opinion that the quality of input is low. This finding is in agreement with Uche 2010 . The students are directly affected by poor quality of resources in their institutions and it is good that now is the time to speak out.

The findings also indicates that the level of academic accountability in terms of the quality of the process is high (overall mean of 2.51, slightly higher than the criterion mean), especially in the areas of leadership in the institutions, appropriate use of language and lecturers' positive attitude. However the level of quality in terms of institutional autonomy, teaching method and incentive for good result is low. 
The transformation process constitutes the basic activities of teaching, learning, evaluation and the managerial elements of the higher educational process. The nature and efficacy of the transformation process is not dependent on one unit but on all the elements of the institutions' programmes. It is at this level that behavioural changes occur and strong character and effective orientation built in the students. Thus effective leadership, use of appropriate language and integrated system for assessment and feedback will be geared towards inculcating a spirit of community and leadership in the students who will eventually go back to the society and become leaders and agents of change in making their contribution to the development of the community (Creech, 1999). The low institutional autonomy as indicated in this study is not good news to the Nigerian higher education, especially as it concerns academic freedom, research and knowledge production. This has been a long running battle between the government and the academics especially in the areas of student admission finance and control and of course demand for academic accountability.

From the opinion of the students and lecturers, the level of academic accountability in terms of the quality of the output is low (criterion mean of 2.48) especially in the level of literacy and citizenship; while the community people's opinion indicated high level (overall mean of 2.68) especially in the achievement of aims of being in school, development of skills and socially accepted values. Lectures and students engage in behaviour modification process that helps the students' build up their characters through training from the on-set. The qualities of the input that are processed to produce the desired outputs were found to be low. This may be attributed to insufficient funding and lack of political willingness to support higher education institutions' programmes and activities. However, the society wants high quality graduates but this cannot be possible without huge investment. In spite of low quality of the output, communities in eastern and Niger Delta states appreciate the graduates from higher education institutions that come from their states. They see these graduates as role model, since most of their youths are school dropouts. Although the high rate of unemployment and unemployable in the country put a big question mark on the achievement of higher education goal.

All categories of respondents agree that research activities by lecturers have made a high degree of impact to the development of community and the institutions. This may be as a result of the impact of community service in the institutions which covers entrepreneurship education, teaching and training for environmental hygiene, campaign for self development, and good citizenship. Interview schedules with the community development chairmen (CDC) also indicated that extra moral classes and community based development projects carried by the lecturers and students have been great interventions in environmental development, health, agriculture, business and political 
empowerment. This recognition is in agreement with Uche, 2009 that reveals high level of student involvement in community development through student in free enterprise projects. Research activities and dissemination of knowledge is another area through which higher education impacts the institutions and the society positively as similarly supported by Agabi \& Uche (2004; Okorie \& Uche, 2005). However, the present study reveals that the level of engineering activities for innovative and adaptive technology is low (2.46). This is worrisome in this era of advancement on local technology. If university research is to assist national development, it must be relevant to the nation's development goals through linkage with industries, community and the world. The higher education should train graduates and scholars that can use local raw materials to develop the technology that will be beneficial to the community and economy of the nation. This is already specified in the National Policy on Education (2004) but the level of its implementation may form a question for another study.

The study also revealed that generally lack of political willingness to support the implementation of higher education policies, political insincerity in the development of higher education, non usage of research findings and gross inadequate funding are major constraints to accountability and quality in higher education. Surprisingly poorly remunerated staff is not a rated as a major constraint in the study.

Generally the major constraints of academic accountability and quality in higher education are lack of political willingness to support the implementation of higher education policies, political insincerity in the development of higher education, non usage of research findings and gross inadequate funding. Surprisingly poorly remunerated staff, low staff strength and lack of competence in the faculty members were scored low by students and lecturers but high by community people. Though this finding is in disagreement with Amadike (2009), it may mean that to the students and lecturers, political insincerity is the main problem to the development of higher education in Nigeria. Once the political will power is exercised every other thing will be put in place. The community people believe that the lecturers are poorly paid and this was reflected in their massive support during the national strike by university workers that led to the federal government/ASUU agreement in 2009 which caused a great increment in the workers' salaries.

\section{Conclusions, Implications and Recommendations}

Higher education in any nation is charged with the development of middle and high level manpower that will contribute to its national and economic 
development. The findings have revealed that the quality of the input is low and this has reflected in the low quality of the output, though the quality of the process was rated high. The implication of the low quality of input and output as revealed in this study is that the higher education is not producing the quality of graduates that will contribute to the national development. It also means that the resources available in the institutions are of low quality. This may explain the reason why there are so many graduates roaming the streets without jobs and skills. This also explains why some companies send newly employed graduates to further training before they can be allowed to start work because the quality cannot be ascertained. This is a worrisome development and puts a big question mark on the academic accountability for the huge resources being spent on higher education. The study also identified lack of political willingness to develop higher education as major constraints to academic accountability and quality. If the leaders are not sincere and willing to develop a system, the quality of its components cannot be guaranteed. That the quality of transformational process; the degree of the impact of research; and community service on development were rated high by the respondents indicates that the people at the operational base are ready to perform if the right inputs and political will power are provided. Academic accountability and quality are two inseparable concepts in higher education that need great emphasis in all ramifications if the higher institutions in Nigeria could join the world in achieving MDGs in 2020. Based on the findings the following recommendations are made:

1. There is need for urgent interventions to improve quality of the input, (both human, material, financial resource), the programmes and other activities in the institutions

2. Lecturers should be given training on quality assurance and other orientation that they will need to account for quality in what they do, how they do it and what they produce

3. Jobs should be created by both government, industries and other individual organizations to absorb the graduates that are being produced from higher education

4. There should be practical sessions for all students at different level to be trained on how to use local materials to create facilities for development irrespective of their field of study to enable them stand on their own when they finish school.

5. Quality should be emphasized at other levels of education (primary and secondary) and all areas of the society from where the students' inputs are taken to make the work of developing the students easier.

6. The political leaders at all levels should develop the right mindset and willingness to develop the nation's higher education as obtainable in other developed world. 
7. More emphasis should be on relevant and functional research, university/industry collaboration to boost innovative and adaptive technology

8. Accountability must be geared towards improving students learning and development. Therefore all stakeholders in education including (higher education) must be involved in accountability through meaningful contribution and in honesty in their respective roles to ensure effective provision of functional education of the upcoming generation

\section{References}

Agabi, O. G. (2002). The Classroom Management System. In Agabi, O. G. \& Okorie, N.C. Eds. (2002). Classroom Management. Bori: Fredsbary Printers and Publishers.1-12.

Agabi, O. G. \& Uche, C. M. (2000). "Management of contract research activities in Nigerian Universities for Alternative Funding for Nigerian Universities System" Nigerian Journal of Empirical Studies in Psychology and Education. Vol. 1.No. 3, 91-98.

Amadike, O. (2009). Quality Control and Assessment in Tertiary Institutions. In Babalola, J. B, Akpa G. D., Ayeni, A.O. \& Adedeji, S. O. (2007). Higher Education, Ibadan: NAEAP 423-430

Altbach, P. G., R. O. Berdahl \& P. J. Gumport (Eds.) (1999). American Higher Education in the Twenty first century: Social, Political and Economic Challenges. The Johns Hopkins University Press. 70-80.

Berdahl, R. O. \& McConnell, T. R. (1999). Autonomy and Accountability: Who controls Academe? In Babalola, J. B. \& Jaiyeoba, A. O. (2008). Curriculum Development for effective Learning in Higher Education during Knowledge and Digital Revolution: The Nigerian Experience. Ibadan: AWEMARY.

Creech, B. (1994). The five Pillars of TQM: How to make Total Quality work for you. New York: Penguin Book Inc.

Crosby, P. B. (1979). Quality is free. New York: Mentor Books.

Gronhind, N. F. (1974). Determining Accountability for classroom Instruction. New York: Macmillan Publishing Co. Inc.

Jaap, S. (2004). The Conceptual Framework for Measuring Quality. (UNESCO Framework). Paper 1 for the EFA Global Monitoring Report 2004. Retrieved from:unesco.org//6526f1b8e91a731fd6a369abaa5Scheerens+Measuring+qua lity+2+March.doc on $10^{\text {th }}$ March 2011.

Jaiyeoba, A. O., Atanda, A. I. (2007). Enhancing the Quality of graduates of College of Education: A means to achieve effective NATIONAL building in 
Nigeria. In Babalola J. B, Akpa G. D., Ayeni, A.O. \& Adedeji, S. O. (2007). Higher Education, Ibadan: NAEAP 431-442

Mechanism in Nigerian Universities through ICT Compliance. In Babalola, J. B, Akpa G. D., Ayeni, A.O. \& Adedeji, S. O. (2007). Higher Education, Ibadan: NAEAP 307-315

Nnabuo, P. O. M., Okorie, N.C., Nwedeeduh, S. B. \& Uche C. M. (2006). Leadership and Supervision in Education. Owerri: TOTAN Publishers Limited

National Policy on Education (2004). Federal Ministry of Education, AbujaNigeria

Obanya, P. (2010). Investing in Quality education in Africa. Education International $(\mathrm{EI}) .7^{\text {th }}$ African regional Conference. Brazzaville: $29^{\text {th }}$ November -02 December 2010.

Total Quality Management (TQM) in Education. Its Imperatives and Key Concepts. In Nnabuo, P. O. M., Okorie, N.C., Agabi, O. G. \& Igwe, L. E. B. (2004). Fundamentals of Educational Management. Owerri: Versatile Publishers. 43-78.

Okorie, N.C. and Uche, C. M. (2004). "University-Industry Interface Activities Awareness of Sponsored Research among Nigerian Academics" Ghana Journal of development studies, Vol. 1 No. 2 (December) 101-117.

Onyene, V. E., Iebude, O. \& Uche C. M. (2009). Quality and Standard Balancing in Nigerian University

Education: Implication for the attainment of Millennium Development Goals. LWATTI A Journal of Contemporary Research. Vol 6 (2).51-64.

Rao, V. K. (2008). Higher Education. New Delhi: A. P. H. Publishing Corporation

Reiley, B. (1992). Total Quality Management in Higher Education. U.S. Department of Education,

Office of Educational Resources and Improvement, Educational Resource Information Centre (ERIC).

Sallis, E. (2002). Total Quality Management in Education, $3^{\text {rd }}$ edition. London: Kogan Page Ltd.

Uche, C. M. (2010). Assessing the Impact of Student Involvement in Community Development: The case of University of Port-Harcourt, Nigeria. International Journal of Education Research. Vol. 5 (1), Winter 2010. 92110.

Uche, C. M., Okoli, N \& Ahunanya, S. (2011). Infrastructural Development and Quality Assurance in Nigerian Higher Education. Journal of Emerging Trends in Educational Research and Policy Studies (JETERAPS). www.scholarlinkresearch.org

Uche, C. M. (2010). Students-Perception of Academic Staff Quality: A Measure of Quality Assurance in South-South Nigerian Higher Institutions. 
A paper presented at the UNESCO organized conference on Quality Assurance in Higher Education in Africa: Setting a Sustainable Agenda for a New Decade in Bamako, Mali, $5^{\text {th }}-7^{\text {th }}$ October, 2010. 